\title{
Sustainable Energy System Development in Local Communities
}

\author{
Giedrius Gecevičius ${ }^{1}$, Jolanta Dvarionien $\dot{e}^{2}$ \\ ${ }^{1}$ Laboratory of Renewable Energy and Energy Efficiency, Lithuanian Energy Institute, Kaunas, Lithuania \\ ${ }^{2}$ Kaunas University of Technology, Institute of Environmental Engineering, Kaunas, Lithuania \\ Corresponding author: \\ G. Gecevičius, Laboratory of Renewable Energy, Lithuanian Energy Institute, Breslaujos St 3, LT-44403 \\ Kaunas, Lithuania \\ E-mail: giedrius.gecevicius@lei.lt
}

\begin{abstract}
This paper analyses an approach to energy saving measures and discusses main obstacles to developing renewable energy sources and energy efficiency in Lithuanian communities. Research results indicate lack of information on renewable energy, and on measures to increase it. A new management system is developed, which makes it possible to manage energy streams in communities by a decision making mechanism, which operates by an algorithm. When energy is managed, all obstacles increasing the energy consumption in communities are removed, ensuring greater energy efficiency and development of renewable sources with a view to implementing the EU targets.

Keywords: sustainable development, sustainable energy system, renewable energy sources, energy efficiency, communities' involvement.
\end{abstract}

\section{Introduction}

A stable energy system in a sustainable development is one of the high priority areas in the EU policy. There the priority of an obligation of $20 \%$ of renewable energy resources is a significant step towards the alternative energy (Klessmann et al., 2011). This index is even higher to Lithuania with $23 \%$ of renewable energy in the country's general renewable energy balance. In estimating the political targets, it should be emphasised that sustainable energy is an integral part of the environment policy (Chaliern and Risch, 2011), which means that improvement of administrative procedures, development of facilities and network integration projects, the quality and on-time national action plans are of great importance.

Sustainable energy development is based on three fundamental policy trends: energy independence, competitiveness and sustainable development. After the closure of the Ignalina Nuclear Power Station, Lithuanian energy dependence has strengthened (Pappas et al., 2013); therefore, about two thirds of electric power is imported from other countries (Russia, Latvia,
Estonia, Belarus). In addition, it should be noted that Lithuania is energetically segregated from West Europe, and in many cases it depends on the Eastern countries by the import of electric power and fossil fuel (mostly natural gas). That affects both high energy costs and other social issues. In securing sustainable development the amount of greenhouse emissions should be reduced increasing the efficiency of energy production, transmission and consumption as well as promoting energy production from nonpolluting resources (Monkevičius, 2010). The issues blocking the development of the use of renewable energy sources for energy production are considered to be connected with the relatively high cost price of such energy in a pay-back period (except big hydropower stations) (Stasiukynas, 2011), also with public resistance and state support. Consequently, as regards the market, technologies, political targets and the aspects of participation of communities, the analysis will be done on the energy from biomass, wind and solar energy, considering the impact of the above mentioned means, transmission possibilities and boundaries (Zaccai, 2011). In Lithuania, in the 
country of plains, hydro energy is considered inadequate due to a negative effect on the environment (Duic' et al., 2013).

Hence, Lithuanian thermal energy issues are to be promptly tackled by making proper decisions (applying the management system) and estimating basic economy components: consumption effect on the environment, costs, workplaces and other criteria (Diakaki et al., 2010). Involvement of the people and communities in sustainable energy development depends not only on the public economical indices, but on a demographic situation and the data defining the social situation (Čiegis and Zeleniūtè, 2008). An emphasis should be placed on the fact that results of the research done in Europe and all over the world show that awareness in the environment sustainability sector is insufficient (Cardoso and Fuinhas, 2010), which means that Europe and Lithuania will have to formulate strategic directions for developing energy awareness with intent to avoid energy dangers of communities (Mihajlov, 2009).

\section{Methods}

To estimate public awareness and knowledge of energy issues and to determine the major disturbance to the development of sustainable energy, a questionnaire survey method was applied. The survey was made electronically on the web page www.apklausa.lt. Referring to the methodology (RENERGY, 2013), with a view to obtain the data to represent Kaunas City (Lithuania), the number of people $(n)$ to be inquired was selected using the following equation:

$$
n=\frac{N \times n_{0}}{\left(N+n_{0}\right)}
$$

where $N$ is the number of households, and $n_{0}$ is determined as follows:

$$
n_{0}=\frac{1}{\mathrm{E}_{0}^{2}}
$$

where $E_{0}$ is estimate error $\left(E_{0}=0.1\right)$.

To estimate the situation in the sector of renewable energy sources and energy efficiency, respondents living in Kaunas were inquired. The survey includes all social groups: students, workers and pensioners. Questions were formed on the grounds of community passivity, i.e. with a view of clearing the information to the biggest and most influential dispersion sources. An interest and application of technologies of renewable energy sources (RES) were assessed; one of the questions was about the main setbacks causing problems in renewable energy sources (RES) and energy efficiency (EE) in Lithuania (RENERGY, 2013).

The environment management system is based on the theory of environment systems. This system is set up on the barriers determined in the questionnaire survey, performing various actions for removing setbacks (disturbance). In the newly developed system, a closed relation with a feed-back mechanism exists (Fig. 1).

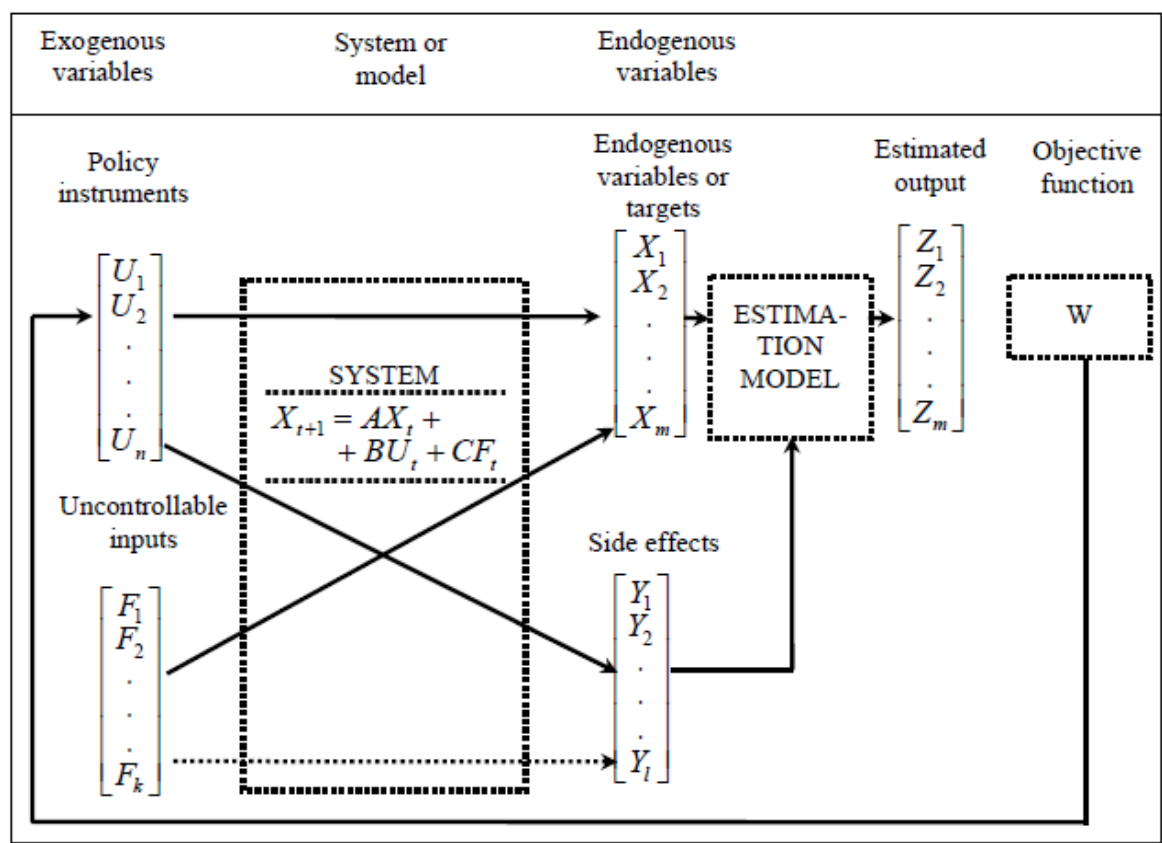

Figure 1. Optimal solution approach (Staniškis, 2001).

This new system consists of four basic parts: object and its description, in which information is presented on energy rate, demography, area, target function (decision-making mechanism), on limits and on controlled as well as uncontrolled setbacks. The principal task of a new system is the process management by a regulation mechanism. On the basis of this mechanism, there lies the selection of measures 
to be used with reference to an algorithm, in other words, to manage the object in the period of time which would change the regulated parameter by an intended target according to a certain law independently of a disturbing effect. The system has controlled $\left(Z_{x}\right)$ and uncontrolled $\left(F_{x}\right)$ disturbances. In this case boundaries of the system are the consumers of energy.

Another important factor in a regulator (in a decision-making mechanism) is an algorithm by means of which a decision is made. When the conditions are satisfactory, namely, (N) X > intended target, then we proceed to the final stage. When the conditions are unsatisfactory $(\mathrm{N}) \mathrm{X}<$ intended target, then we proceed to the next stage; when the conditions cannot be met, then we proceed to the next step. If in the final step, the conditions are unsatisfactory, we proceed to the first step (Staniškis, 2001).

In this research, a survey was carried out, and 103 inhabitants were questioned, while a minimal estimate sum being 100 inhabitants $(n=99.93)$ (see equation (1)). The survey results are presented in percentage with an intention to reliably estimate the behaviour and trends of respondents, there being 139,649 in households in Kaunas City (Statistics Lithuania, 2013).

\section{Results and discussion}

Proper education is one of the best indices for increasing public awareness. As it is mentioned above, the inhabitants of Kaunas are not sufficiently acquainted with the ways of acquiring information about RES and EE integration. As to the question about the main sources of information in the region, most respondents indicated the internet and the media ( $76 \%$ and $74 \%$, respectively). It shows that state authorities have to escalate information measures. Educational institutions (40\%), exhibitions and other information events (45\%) as sources of information are known to less than half of respondents. The activity of business enterprises and state institutions to inform inhabitants makes up less than $10 \%$ of the sources (Fig. 2). These results show that the best source of information is the mass media, whereas in educational institutions this subject is treated insufficiently. This situation reveals that the subject of environmental protection is instructed too little as consciousness and knowledge are to be developed in educational institutions from the very early age. In the planning of alternative energy such learning is suggested to the non-formal study courses.

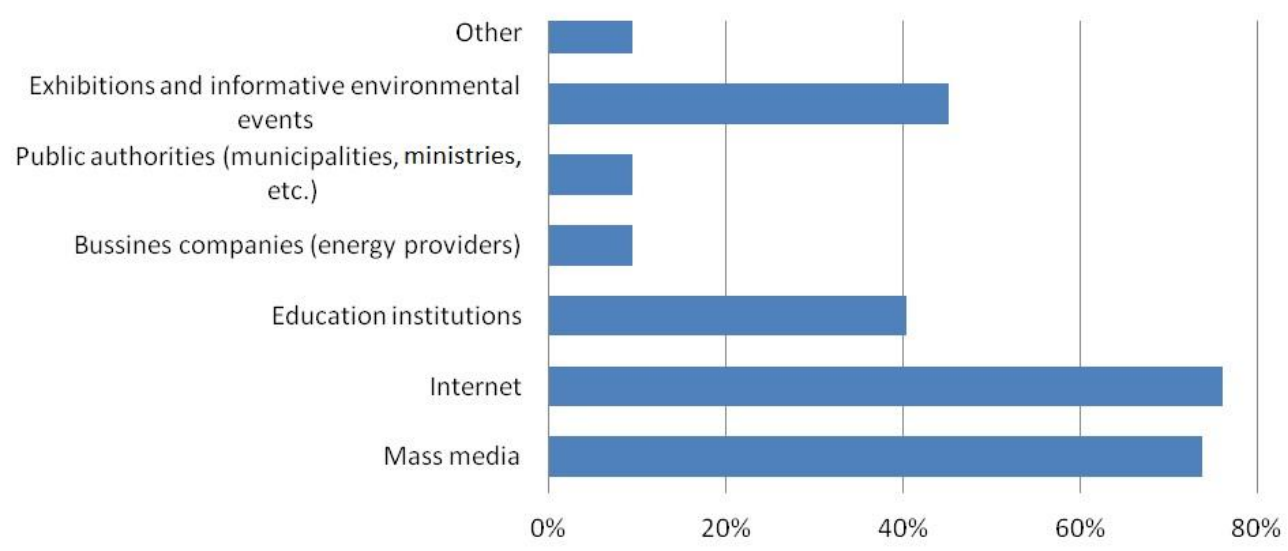

Figure. 2 Questionnaire survey results (Information sources on EE and AEI measures).

Estimating RES technologies, the questionnaire asks what technology is used, what technology interests respondents and what technology they intend to buy. The greatest interest is shown in solar collectors (64\%) and small wind-power plants (54\%). Respondents do not say that they use these technologies, but $7 \%$ of them say they intend to acquire solar collectors, $5 \%$ of them photovoltaics and $2 \%$ of them small wind turbines, which demonstrates that in the future the demand for RES technologies will grow, which will cut the prices in the competitive market. As to biomass, $7 \%$ of respondents use biofuel as an energy source while $2 \%$ of them intend to use it, whereas $40 \%$ of respondents say that they are interested in biofuel as a renewable energy source
(Fig. 3). It should be noted that speaking about biofuel respondents have wood burning in mind. Burning of straw pellets and wood chips is not popular, and the majority of respondents have no intention to install this technology. Geothermal energy interests a lot of respondents (45\%); however, only $2 \%$ of them are going to install it. Thus, in Lithuania this sector of energy is not a promising one. Small hydropower stations and other renewable energy sources have attracted very little attention. In general, it may be said that people are rather sufficiently interested in the solar and biomass energy, but have some doubts about their choice. It indicates their insufficient knowledge and their poorly developed awareness. 


\section{RES technologies installed}

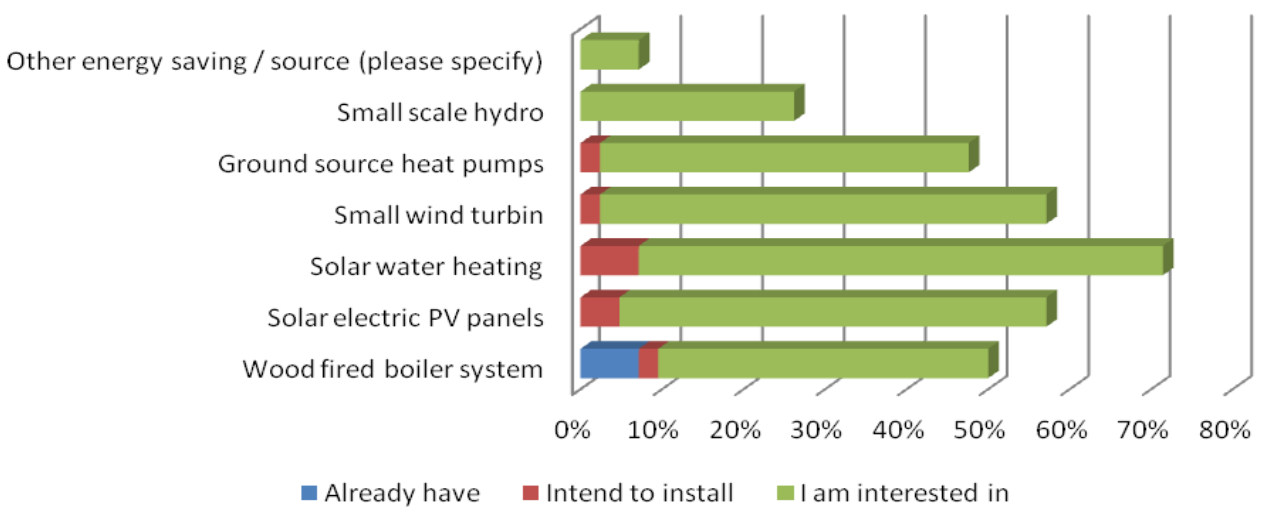

Figure 3. Results of the survey (Which RES technologies do you already use?).

Inhabitants are one of the stakeholders who are the most interested in the introduction of sustainable renewable energy management systems, energy efficiency and renewable resources technologies (Yablecki et al., 2009); therefore, it is very important to determine the setbacks which they have noticed. When asked about the setbacks blocking the introduction of EE and RES, one third of respondents have answered that it is inappropriate to their household thus showing their poor knowledge about it. It is too expensive for $26 \%$ of respondents. These data reveal that there exists a lack of information about the possibilities of submitting applications for financial support from special funds, e.g. the Lithuanian Environmental Investment Fund (LAAIF). In addition, inhabitants lack information about the installation of the RES system. Other barriers including low awareness of the principles of this system, bureaucratic disturbances, being satisfied with the present situation are mentioned by $7-10 \%$ of respondents (Fig. 4).

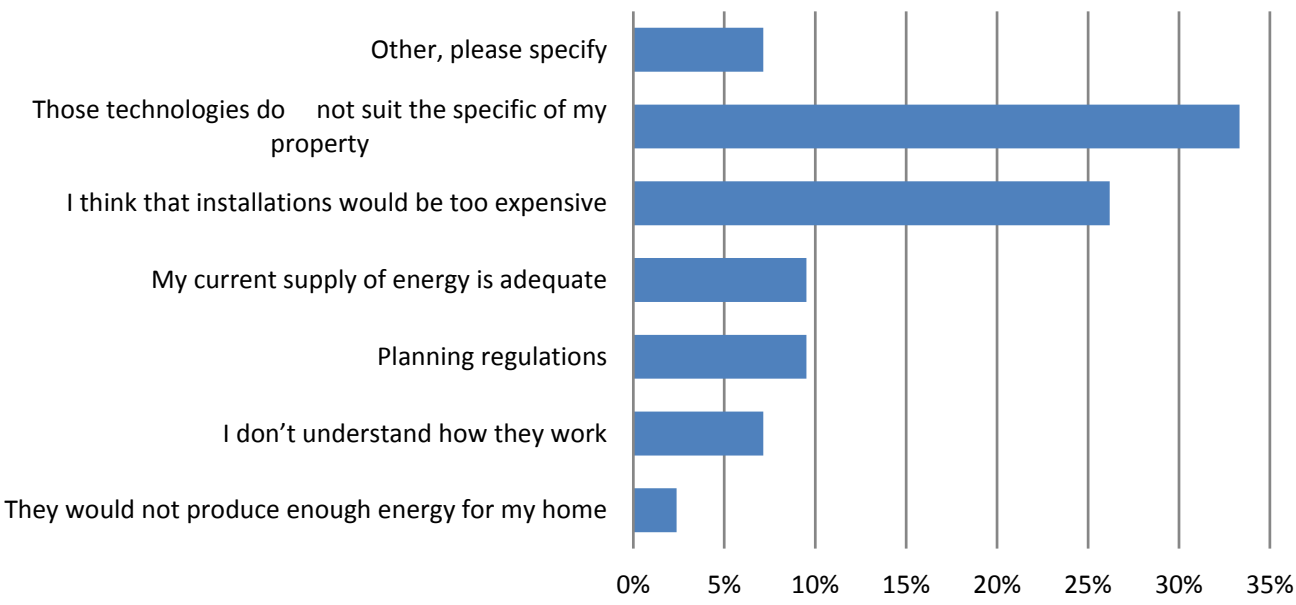

Figure 4. Results of the survey (Barriers blocking development of EE and RES).

To sum up, it may be said that such public consciousness is because of the weak information system resulting in underdevelopment of renewable resources and energy efficiency measures. Introduction of renewable resources faces various barriers, and huge investments are one of them.

To solve these problems it is suggested that the environment management system based on the theory of systems be applied.

\section{Management system}

The effect of an energy efficiency model is based on the combined management system (Fig. 5) mentioned in the methodology. Analysing such system, the model of an object is to be defined, i.e. the situation is to be distinctly estimated. The object is the amount of thermal and electric energy that is to be reduced by introducing renewable sources and energy efficiency measures. In the country, $20 \mathrm{TWh}$ of electric and thermal energy (district heating system) is consumed per year. The population of Lithuania is 3.2 million, and its greater part is energy consumers. One of the targets of the Europe 2020 strategy is to increase the energy efficiency by $20 \%$, i.e. about $1.5 \%$ per year. In the system, the boundaries of one year and LTL 1 billion are defined. The investments for the development of renewable resources and energy efficiency are allotted following the algorithm (Fig. 6). 


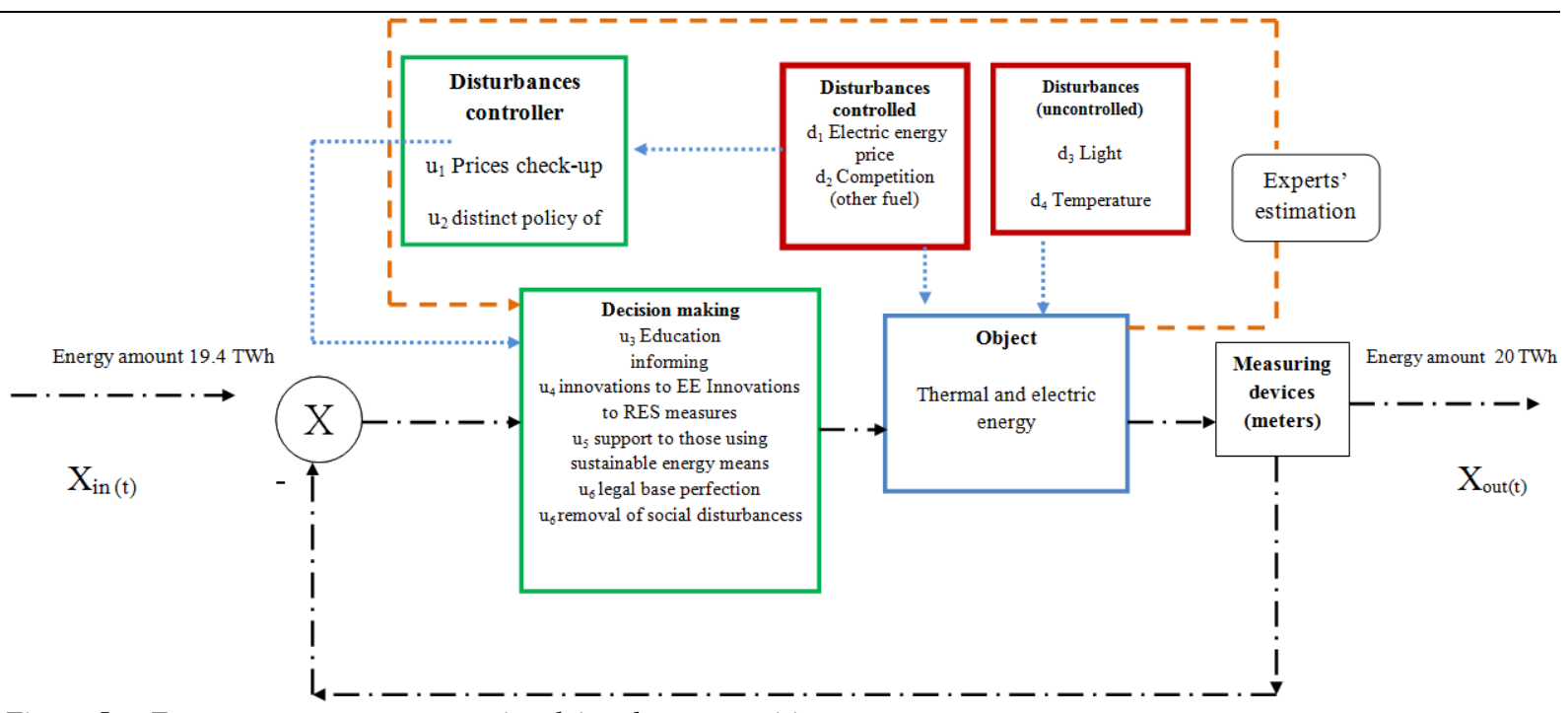

Figure 5. Energy management system involving the communities.

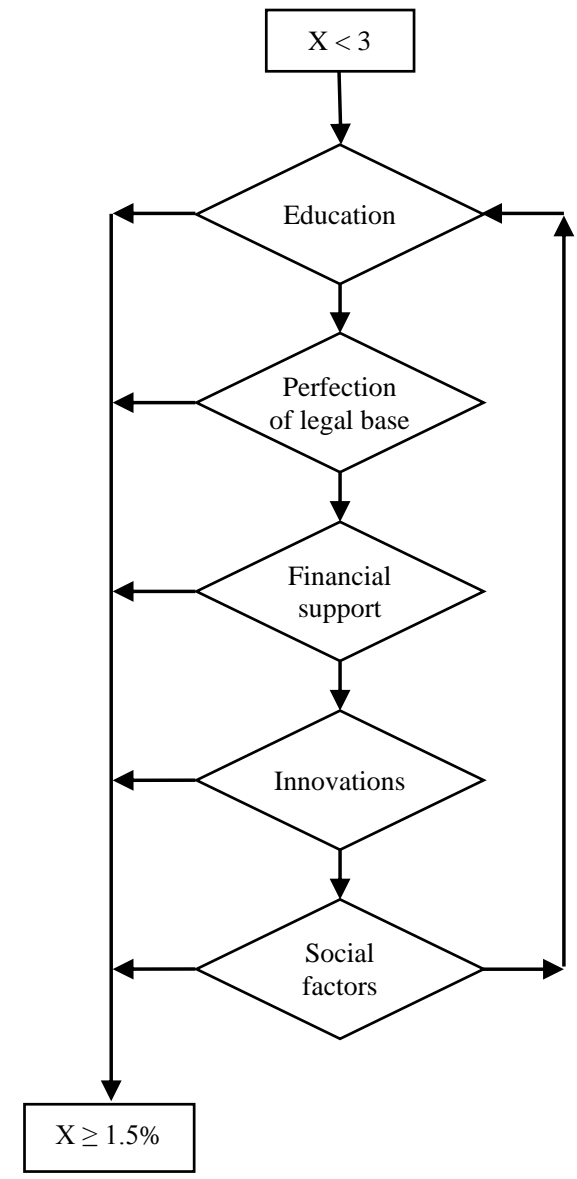

Figure 6. Decision making algorithm.

Making decisions of the system is based on the information supplied by inhabitants on the measures of renewable sources development. To find an optimal solution in a decision making mechanism, an algorithm is applied whose action is based on $\mathrm{X}<1.5$ value. The $1.5 \%$ value indicates the amount of energy as a percentage, which is to be reduced per year. As it has been mentioned, in Lithuania (and all over the world) public awareness of energy efficiency and renewable sources is highly insufficient (according to the experts); therefore, the first step of the algorithm public education - is significant (Rae and Bradley,
2012). In many cases people accept an attitude towards an increase in energy efficiency, but herewith they do not want to take any initiatives (Rogers et al., 2008). If this step is not taken and the energy is not saved by $1.5 \%$ a year, the legal base will be further perfected for developing sustainable energy, because the results of the research done all over the world indicate that legal acts and policy play a very important role when communities are engaged in developing the energy sector (Walker, 2008). By implementing this move, but not meeting the $\mathrm{x}$ value, inhabitants should be given some support. If in both cases this $1.5 \%$ efficiency is not reached, the innovations concerning economical use and ecological production of energy should be better budgeted, i.e. by financing RES GDP is developed, which generates the benefits to the country and pays back in a relatively short time (Menegaki, 2010).

If this value is not satisfied, more attention should be paid to removal of social disturbances such as suspension of social allowances to those who refuse to introduce more efficient energy consumption means. In fact, it is very important not to forget the impact of different social groups. The biggest influence in RES development section is the financing of the strongest social group - workers, but on the other hand, in energy saving sector, there is the same influence of social groups in decision making process.

When the latter is implemented, but the values are not satisfied, then the algorithm steps have to be repeated. In any step, when the algorithm value is satisfied, we proceed to the final stage. The principal aim of this management system is the increase in energy efficiency measured by electric and power energy, thus the electric and power energy is an object of the system. The value of the object of the system is estimated by a negative feed-back, which means that when the system is subjected to negative controlled and uncontrolled disturbances and the target is not reached, then the negative relation sends the signal to the input mechanism, which works following the principle of an algorithm. The operation of the system is estimated mechanically by meters and by experts' evaluation of the quality of intended targets. In the 
analysis of the management system, the potential disturbances are to be optimally estimated. In the analysed management model, disturbances are divided into controlled $\left(\mathrm{d}_{1}, \mathrm{~d}_{2}\right)$ and uncontrolled $\left(\mathrm{d}_{3}, \mathrm{~d}_{4}\right)$. Uncontrolled disturbances are mostly abiotic factors such as temperature or light, which can significantly increase the energy consumption. Controlled disturbances capable of affecting the system are evaluated following some criteria like economy, environment protection and social factors. In this case, the controlled disturbances are electric energy cost (with the costs cut, consumption grows up) and less polluting fuel replaced used to produce energy (when biofuel is used, consumers increase the energy consumption because they assume that fuel has no impact on the environment). To compensate these disturbances, a disturbances' compensation mechanism has been developed marked by $u_{1}$ (checkup price control) and $u_{2}$ (explicit energy policy). The major role of the National Commission for Energy Control and Prices is to determine and maintain costs stability among various types of fuel. The steady electric and thermal energy costs may be a controller in more efficient energy consumption, because it would allow specialists to make concrete assessment of the energy efficiency. A significant reduction in the energy costs would enable consumers to increase the energy consumption thus increasing an impact on the environment. With an energy cost rise, the energy consumption might fall down or remain steady and it would cause higher consumers' expenses for energy. An increase in expenses in this sector may cause bigger poverty in the society on low income. The positive energy policy pointing the Lithuanian development towards renewable or nuclear energy would make it possible to compensate fuel competition and energy costs. In other words, promoting the renewable energy development no privileges would be conferred to technologies burning natural gas from Russia.

Also, it is very important to mention that municipal solid waste (MSW) has one of the biggest energy potential for heat power in Lithuania including Kaunas. At this moment, only one combined heat and power and municipal waste incineration plant exists in Lithuania (Klaipeda). But there are plans to build this type heat and electricity generation plants in Kaunas and Vilnius. For these reasons, it is very important to emphasise that one of the biggest social barriers is residents' protests against municipal waste incineration plants integration.

Actually, the operation of the system guarantees a straight feed-back, compensation of disturbances, the right decision making at each stage. It should be emphasised that implementing this management system each region must determine both the barriers (like a negative community attitude) to the factors blocking the sustainable energy development and the system boundaries which when reached make a shift to another stage possible.

\section{Conclusions}

The questionnaire survey has indicated that educational and state institutions devote too little attention to public education about sustainable energy. For this reason, in Lithuania the main installed RES power plants are huge CHP or wind turbines; small scale solar collectors, photovoltaics and wind turbines as an alternative energy source are not popular among the majority of Lithuanians. The rest of the population assume that it is expensive and its pay-back takes too long time.

People responding to the main disturbance blocking the development of alternative energy sources state that these technologies do not suit their households and do not supply a sufficient amount of energy. This confirms their low awareness of the sustainable energy. Additionally, they point out that state institutions have shown a complete lack of concern for educational activities in this sphere, i.e. their energy policy is based on burning fossil fuel.

A new management system developed on the decision making mechanism set up on the basis of the barriers determined from the survey allows specialists to take an optimal decision by means of an algorithm for achieving the intended target, i.e. to increase electric and thermal energy efficiency by $20 \%$ in each stage proceeding to the next step when the limits of the system are reached, in other words, when the allotted financing is spent.

Functioning of the system is guaranteed by the feedback and compensation of controlled disturbances such as fluctuation of costs, stimulation of competitiveness thus warranting that the target of the system (increase in energy efficiency by $20 \%$ by 2020) will be really achieved.

\section{Acknowledgements}

Authors gratefully acknowledge the contribution of all the team of Kaunas University of Technology, the Institute of Environmental Engineering, who helped to develop the environmental management system.

\section{References}

Charlier, D., and Risch, A. (2012) Evaluation of the impact of environmental public policy measures on energy consumption and greenhouse gas emissions in the French residential sector. Energy Policy 46: 170-84. doi: http://dx.doi.org/10.1016/j.enpol.2012.03.048.

Ciegis, R., Zeleniute, R. (2008) Sustainable Development Aspects of Lithuanian Economic Development. Applied Economics: Systematic Research 2(1): 35-52.

Diakaki, Ch., Grigoroudis, E., Kabelis, N., Kolokotsa, D., Kalaitzakis, K., Stavrakakis, G. (2010) A multiobjective decision model for the improvement of energy efficiency in buildings. Energy 35: 5483-96. doi: http://dx.doi.org/10.1016/j.energy.2010.05.012.

Duic', N., Guzovic, Z., Kafarov, V., Klemeš, J.J., Mathiessen, B., Yan, J. (2013) Sustainable development of energy, water and environment systems. Applied 
Energy 101: 3-5. doi: http://dx.doi.org/10.1016/ j.apenergy.2012.08.002.

Juknys, R. (2010) Expansion possibilities of renewable energy sources in the framework of sustainable development. Sustainable development strategy and practise 1(4): 4-10.

Klessmann, C., Held, A., Rathmann, M., Ragwitz, M. (2011) Status and perspectives of renewable energy policy and deployment in the European Union - What is needed to reach the 2020 targets? Energy Policy 39: 7637-57. doi: http://dx.doi.org/10.1016/j.enpol.2011.08. 038.

Marques, A.C., Fuinhas, J.A. (2012) Are public policies towards renewables successful? Evidence from European countries. Renewable Energy 44: 109-18. doi: http://dx.doi.org/10.1016/j.renene.2012.01.007.

Menegaki, N. (2011) Growth and renewable energy in Europe: A random effect model with evidence for neutrality hypothesis. Energy Economics 33: 257-63. doi: http://dx.doi.org/10.1016/j.eneco.2010.10.004.

Mihajlov, A. (2010) Opportunities and challenges for a sustainable energy policy in SE Europe: SE European Energy Community Treaty. Renewable and Sustainable Energy Reviews 14: 872-75. doi: http://dx.doi.org/ 10.1016/j.rser.2009.10.026.

Monkevicius, E. (2010) Environmental Legal Problems in the Context of Globalization. Jurisprudence 1(119): 197-210.

Pappas, C., Karakosta, C., Marinakis, V., Psarras, J.A. (2012) A comparison of electricity production technologies in terms of sustainable development. Energy Conversion and Management 64: 626-32. doi: http://dx.doi.org/10.1016/j.enconman.2012.06.006.

Rae, C., Bradley, F. (2012) Energy autonomy in sustainable communities - A review of key issues. Renewable and Sustainable Energy Reviews 16: 6497-506. doi: http://dx.doi.org/10.1016/j.rser.2012.08.002.

RENERGY (2013). Self-assesment analysis. Kaunas, Lithuania.

Rogers, J.C., Simmons, E.A., Convery, I., Weatherall, A. (2008) Public perceptions of opportunities for community-based renewable energy projects. Energy Policy 36: 4217-4226. doi: http://dx.doi.org/10.1016/ j.enpol.2008.07.028.

Staniškis, J.K. (2001) Environmental Management: Strategies and Implementation. Environmental research, engineering and management 2(16): 3-10.

Stasiukynas, A. (2011) Analysis of promotion of measures for the use of renewable energy sources in electricity sector. Journal of young scientist 1(30): 55-63.

Statistics Lithuania (2013), Households, 2011. Available at: http://osp.stat.gov.lt/documents/10180/217110/2011_G BSataskaita.pdf (accessed: 17/9/2013).

Walker, G. (2008) What are the barriers and incentives for community-owned means of energy production and use? Energy Policy 36: 4401-05. doi: http://dx.doi.org/ 10.1016/j.enpol.2008.09.032.

Yablecki, J., Bibeau, E.L., Smith, D.W. (2011) Communitybased model for bioenergy production coupled. Biomass and Bioenergy 35: 2561-2569. doi: http://dx.doi.org/ 10.1016/j.biombioe.2011.02.011.

Zaccai, E. (2012) Over two decades in pursuit of sustainable development: Influence, transformations, limits. Environmental Development 1: 79-90. doi: http://dx.doi.org/10.1016/j.envdev.2011.11.002. 


\title{
Darni energetikos plètra vietos bendruomenèse
}

\author{
Giedrius Gecevičius ${ }^{1}$, Jolanta Dvarioniene $\dot{~}^{2}$ \\ ${ }^{1}$ Atsinaujinančiu ištekliu ir efektyvios energetikos laboratorija, Lietuvos energetikos institutas, Kaunas, Lietuva \\ ${ }^{2}$ Aplinkos inžinerijos institutas, Kauno technologijos universitetas, Kaunas, Lietuva
}

\begin{abstract}
Straipsnyje apžvelgiamos ir tiriamos energijos taupymo priemonės bei pagrindinės kliūtys, trukdančios skatinti efektyvų energijos vartojimą ir plètoti atsinaujinančiuosius energijos išteklius, taip pat aprašomas unikalios šilumos ir elektros energijos valdymo sistemos vietos bendruomenėse taikymas. Atlikus tyrimą gauti rezultatai rodo, jog gyventojai neturi pakankamai informacijos atsinaujinančiosios energijos bei energetinio efektyvumo didinimo srityse. Sukurta valdymo sistema leidžia valdyti energijos srautus remiantis sprendimu prièmimo mechanizmu, kuris veikia algoritmo pagalba. Valdant srautus yra pašalinamos visos kliūtys, skatinančios didesnị energijos poreikį, taip užtikrinant efektyvesni energijos vartojimą bei atsinaujinančiujų energijos ištekliu plètrą, siekiant igyvendinti Europos Sajungos tikslus.

Raktiniai žodžiai: darnus vystymasis, darni energetika, atsinaujinantieji energijos šaltiniai, energijos vartojimo efektyvumas, bendruomenès.
\end{abstract}

